\title{
Bone Microstructure of Mice After Prolonged Taurine Treatment
}

\author{
M. MARTINIAKOVA ${ }^{1}$, A. SAROCKA ${ }^{1}$, R. BABOSOVA ${ }^{1}$, D. GALBAVY $^{2}$, E. KAPUSTA ${ }^{3}$, \\ Z. GOC ${ }^{3}$, G. FORMICKI ${ }^{3}$, R. OMELKA ${ }^{4}$ \\ ${ }^{1}$ Department of Zoology and Anthropology, Faculty of Natural Sciences, Constantine the \\ Philosopher University in Nitra, Slovak Republic, ${ }^{4}$ Department of Botany and Genetics, Faculty of \\ Natural Sciences, Constantine the Philosopher University in Nitra, Slovak Republic, ${ }^{2}$ Private \\ Orthopedic Ambulance, Nitra, Slovak Republic, ${ }^{3}$ Department of Animal Physiology and \\ Toxicology, Institute of Biology, Faculty of Geography and Biology, Pedagogical University in \\ Cracow, Poland
}

Received February 12, 2019

Accepted March 19, 2019

\begin{abstract}
Summary
Taurine, a sulphur - containing amino acid, has been termed a functional nutrient. Its synthetic form is a common ingredient in supplements and energy drinks. There is no information concerning taurine impact on bone microstructure after prolonged supplemental use. Also, differences in bone parameters of mice following taurine exposure are unknown. In this study, a detailed microstructure of compact and trabecular bone tissues of mice subchronically exposed to taurine was determined. Animals $(n=12)$ were segregated into three groups: E1 group - mice received $20 \mathrm{mg} / \mathrm{kg}$ b.w. of taurine per day during 8 weeks; E2 group - mice were fed by taurine at a dose of $40 \mathrm{mg} / \mathrm{kg}$ b.w. for 8 weeks and a control (C) group. Decreased density of secondary osteons, increased sizes of primary osteon's vascular canals $(P<0.05)$ were observed in taurine - treated animals. Cortical bone thickness, trabecular thickness were decreased $(P<0.05)$ in $E 1$ group, and relative volume of trabecular bone was lower $(P<0.05)$ in $E 2$ group as compared to $C$ group. According to our results, prolonged taurine exposure at the doses used in this study can negatively affect both compact and trabecular bone tissues microstructure.
\end{abstract}

\section{Key words}

Taurine • Bone $\bullet$ Mouse $\bullet$ Microstructure

\section{Corresponding author}

M. Martiniakova, Department of Zoology and Anthropology, Faculty of Natural Sciences, Constantine the Philosopher
University in Nitra, Nábrežie mládeže 91, 94974 Nitra, Slovak Republic. E-mail: mmartiniakova@ukf.sk

Taurine (2-ethanesulfonic acid) might be a pertinent candidate for use as a nutritional supplement to protect against oxidative stress, diabetes mellitus, neurodegenerative diseases or atherosclerosis (Bouckenooghe et al. 2006). A synthetic form of taurine is a key ingredient in supplements and energy drinks. Since most clinical trials to date have looked at the effects of taurine in combination with other ingredients such as caffeine, creatine, and glucose in energy drinks, these studies cannot be used to determine the effects of taurine alone (Caine and Geracioti 2016). It is reported that Red Bull ${ }^{\circledR}$ energy drink $(0.4 \%$ of taurine) caused increased diastolic blood pressure, aerobic endurance and anaerobic performance (Oja and Saransaari 2007). Taurine should neutralize several untoward effects of caffeine in the drinks, e.g. while caffeine is capable of elevating blood pressure, taurine reduces blood pressure (Schaffer et al. 2014).

Taurine is known to play an important role in bone health as well. According to several studies, it affects bone in rats favorably. The addition of $2 \%$ taurine in control diet increases femur BMC per weight in growing rats (Choi and Seo 2013). Taurine supplemented diets may have positive results on bone metabolism in alcohol-fed OVX rat model (Choi et al. 2017). According 
to Choi (2017), taurine may modulate bone in cholesterol fed estrogen deficiency-induced rats. However, all these results were obtained after 6 weeks of taurine treatment in rats which is equivalent to 1.5 bone remodeling cycle. There is no information concerning taurine impact on bone microstructure after prolonged supplemental use. Also, differences in bone parameters of mice following taurine exposure are unknown.

Therefore, twelve clinically healthy 4-month-old Swiss mice were used in this experiment. We used the males because they are less susceptible to skeletal damage than females (Riggs et al. 2004). The animals were obtained from the accredited experimental laboratory of the Pedagogical University in Cracow (Poland) where the experimental part with animals was set out. Mice were randomly divided into three experimental groups of 4 animals each and were treated perorally with taurine during 8 weeks (it corresponds to 4 bone remodeling cycles in mice). In E1 group, males received $20 \mathrm{mg} / \mathrm{kg}$ b.w. of taurine per day; in E2 group received taurine at the dose of $40 \mathrm{mg} / \mathrm{kg} \mathrm{b.w}$. and a group without taurine administration served as control (C) one. The solution of taurine in water has been made every day and it was administered orally to mice by a syringe. The doses used in our study are consistent with a taurine content in 1.5 (E1 group) and 3 (E2 group) bottles of Red Bull energy drink $(250 \mathrm{ml})$ consumed daily for $75 \mathrm{~kg}$ male adults. All the applied procedures were approved by the First Local Ethic Committee on Experiments on Animals in Cracow (resolution number 175/2012).

At the end of treatment period, mice were killed and their femurs were used for microscopical analyses. Thin sections $(70-80 \mu \mathrm{m})$ were prepared according to Martiniaková et al. (2006). The qualitative $2 \mathrm{D}$ characteristics of the compact bone were determined according to Enlow and Brown (1956) and Ricqlés et al. (1991). The quantitative (morphometrical) 2D parameters of the compact bone were assessed using the software Motic Images Plus 2.0 ML (Motic China Group Co., Ltd., Xiamen, China). The sizes of vascular canals of primary osteons, Haversian canals and secondary osteons were measured in all views (anterior, posterior, medial, lateral) of thin sections.

Quantitative 3D analysis of compact and trabecular bone tissues were determined using microcomputed tomography ( $\mu \mathrm{CT} 50$, Scanco Medical, Switzerland). Compact bone structure was analysed in a region of interest starting $5.2 \mathrm{~mm}$ from the border between the shaft and the distal end and extending
$1.5 \mathrm{~mm}$ at femoral midshaft. Following parameters were measured: relative bone volume with and without marrow cavity, bone mineral density (BMD), bone surface and cortical bone thickness. Trabecular bone structure was analysed in a region of interest starting $1.2 \mathrm{~mm}$ from the border between the shaft and the distal end and extending $1.5 \mathrm{~mm}$. We measured bone surface, relative bone volume, trabecular number, trabecular thickness and trabecular separation.

Statistical analysis was performed using SPSS 8.0 software. All data were expressed as mean \pm standard deviation. The unpaired Games-Howell's and/or Tukey's tests were used for establishing statistical significance $(\mathrm{P}<0.05)$ among all groups.

Endosteal and periosteal surfaces of femora in mice from the $\mathrm{C}$ group consisted of non-vascular bone tissue (in anterior, medial and lateral views), which contained cellular lamellae and osteocytes. In posterior part of endosteal border, primary vascular radial bone tissue was observed. This tissue included vascular canals (branching or non-branching) radiating from the marrow cavity. In the middle parts of the compact bone a few resorption lacunae were identified (Fig. 1a). These results are in accordance to those of other researchers (Enlow and Brown 1956, Reim et al. 2008, Treuting and Dintzis 2011).

In our study, differences in compact bone microstructure of mice from E1 and E2 groups were detected. Taurine - treated mice had a decreased density of secondary osteons ( $-23 \%$ in E1 group, $-33 \%$ in E2 group) in the middle part of the compact bone. In addition, primary vascular radial bone tissue was not present in posterior part of endosteal border in both E1, E2 groups (Fig. 1b, c). These results suggest a decreased endocortical bone remodeling after prolonged taurine administration.

In total, 426 vascular canals of primary osteons, 51 Haversian canals and 51 secondary osteons were measured. The results are summarized in Table 1A. The sizes of the primary osteon's vascular canals were significantly increased $(\mathrm{P}<0.05)$ in groups $\mathrm{E} 1, \mathrm{E} 2$ when compared to the $\mathrm{C}$ group. Haversian canals and secondary osteons values did not differ significantly among all groups. Vasodilation of primary osteon's vascular canals could be associated with a vasoactive effect of taurine on blood vessels (El Idrissi et al. 2013). Blood vessels are present in both primary osteons and Haversian canals. Unlike primary osteons, Haversian canals are surrounded by a cement line (Martiniakova et al. 2013). Therefore we assume that the cement line could be the main reason for these differences. 


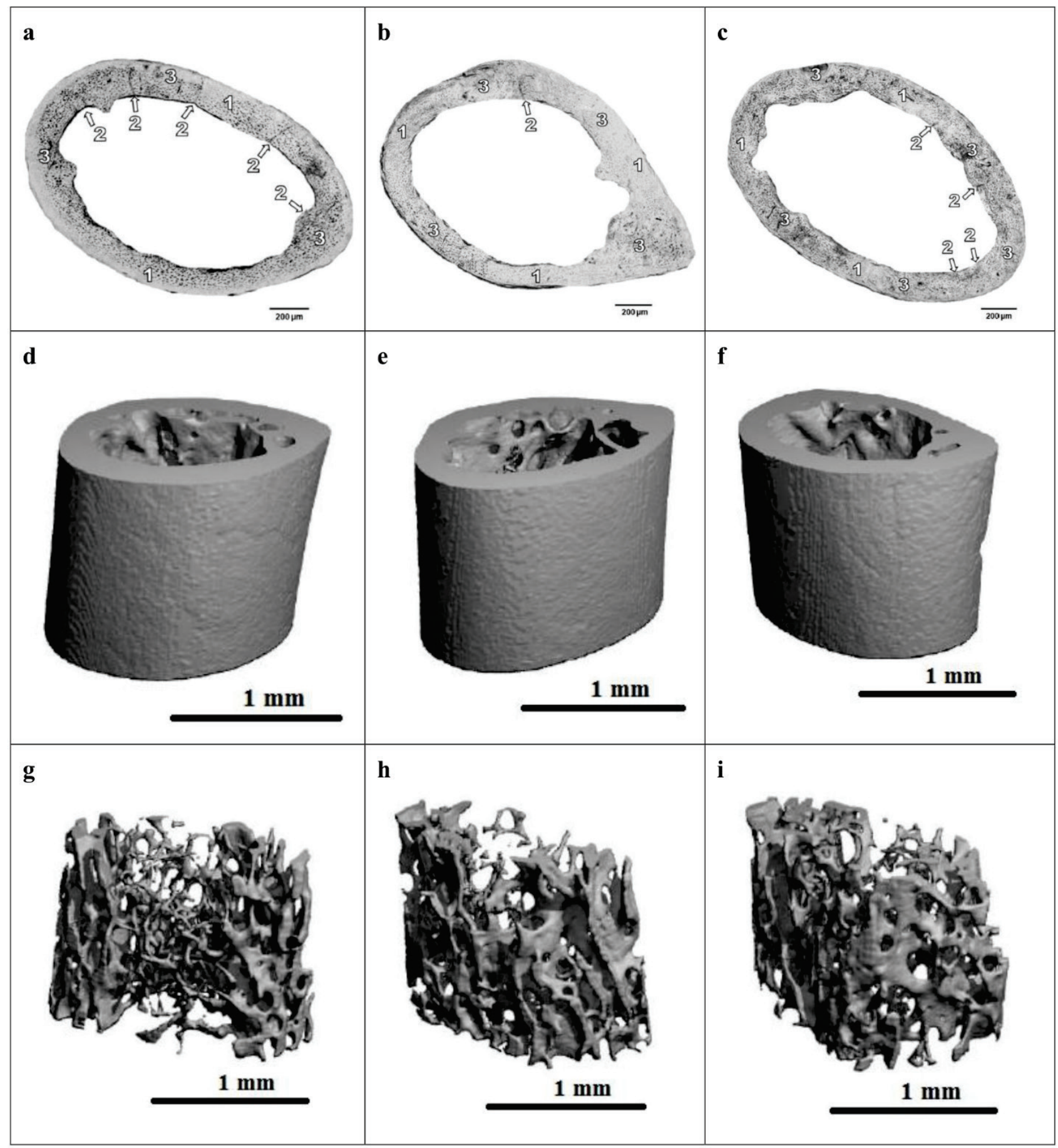

Fig. 1. Representative $2 \mathrm{D}$ and $3 \mathrm{D}$ images of compact and trabecular bone tissues in mice. (a) microscopic structure of compact bone in mice from C group. (b) microscopic structure of compact bone in mice from E1 group. (c) microscopic structure of compact bone in mice from E2 group. (1 - non-vascular bone tissue, 2 - primary vascular radial bone tissue, 3 - irregular Haversian bone tissue). (d) representative reconstructed 3D image of the compact bone in mice from $\mathrm{C}$ group, (e) representative reconstructed 3D image of the compact bone in mice from E1 group. (f) representative reconstructed 3D image of the compact bone in mice from E2 group. (g) representative reconstructed 3D image of the trabecular bone in mice from C group. (h) representative reconstructed 3D image of the trabecular bone in mice from E1 group. (i) representative reconstructed 3D image of the trabecular bone in mice from E2 group.

Quantitative 3D analysis of the compact bone discovered significantly decreased cortical bone thickness in E1 group in comparison to C, E2 groups (Table 1B, Fig. 1d-f). In the trabecular bone, trabecular thickness was decreased in E1 group and relative bone volume was significantly lower in E2 group as compared to the $\mathrm{C}$ group. The results are summarized in Table 1C. Representative reconstructed 3D images of the trabecular bone are illustrated in Figures 1g-1i. According to our results, taurine exposure can negatively affect both 
Table 1. Morphometrical results.

\begin{tabular}{|c|c|c|c|c|c|c|}
\hline \multicolumn{7}{|c|}{ A. Quantitative 2D analysis of compact bone tissue } \\
\hline $\begin{array}{l}\text { Measured } \\
\text { structures }\end{array}$ & Group & $\mathbf{n}$ & $\begin{array}{l}\text { Area } \\
\left(\mu \mathbf{m}^{2}\right)\end{array}$ & $\begin{array}{c}\text { Perimeter } \\
(\mu \mathrm{m})\end{array}$ & $\begin{array}{c}\text { Max. diameter } \\
(\mu \mathrm{m})\end{array}$ & $\begin{array}{c}\text { Min. diameter } \\
(\mu \mathrm{m})\end{array}$ \\
\hline \multirow{4}{*}{$\begin{array}{l}\text { Primary } \\
\text { osteons' } \\
\text { vascular } \\
\text { canals }\end{array}$} & $\mathrm{C}(1)$ & 135 & $20.46 \pm 3.47$ & $16.06 \pm 1.38$ & $2.65 \pm 0.29$ & $2.40 \pm 0.23$ \\
\hline & E1 (2) & 147 & $23.53 \pm 3.88$ & $17.23 \pm 1.40$ & $2.83 \pm 0.23$ & $2.60 \pm 0.31$ \\
\hline & E2 (3) & 144 & $26.04 \pm 3.93$ & $18.22 \pm 1.40$ & $3.06 \pm 0.33$ & $2.69 \pm 0.32$ \\
\hline & \multicolumn{2}{|c|}{$\begin{array}{l}\text { Games-Howell } \\
\text { test }\end{array}$} & $1: 2^{*} ; 1: 3^{*} ; 2: 3^{*}$ & $1: 2 * ; 1: 3 * ; 2: 3^{*}$ & $1: 2 * ; 1: 3 * ; 2: 3 *$ & $1: 2^{*} ; 1: 3^{*}$ \\
\hline \multirow{4}{*}{$\begin{array}{l}\text { Haversian } \\
\text { canals }\end{array}$} & $\mathrm{C}(1)$ & 21 & $22.65 \pm 3.40$ & $16.96 \pm 1.29$ & $2.84 \pm 0.26$ & $2.50 \pm 0.29$ \\
\hline & E1 (2) & 16 & $23.53 \pm 5.08$ & $17.17 \pm 1.89$ & $2.83 \pm 0.37$ & $2.60 \pm 0.31$ \\
\hline & E2 (3) & 14 & $20.66 \pm 4.26$ & $16.06 \pm 1.65$ & $2.60 \pm 0.31$ & $2.47 \pm 0.28$ \\
\hline & \multicolumn{2}{|c|}{ Tukey test } & NS & NS & NS & NS \\
\hline \multirow{4}{*}{$\begin{array}{l}\text { Secondary } \\
\text { osteons }\end{array}$} & $\mathrm{C}(1)$ & 21 & $298.99 \pm 61.28$ & $61.89 \pm 6.64$ & $10.77 \pm 1.32$ & $8.81 \pm 1.24$ \\
\hline & E1 (2) & 16 & $321.73 \pm 68.05$ & $63.96 \pm 7.01$ & $11.00 \pm 1.49$ & $9.28 \pm 1.08$ \\
\hline & E2 (3) & 14 & $343.93 \pm 75.46$ & $66.20 \pm 7.32$ & $11.48 \pm 1.42$ & $9.46 \pm 1.17$ \\
\hline & \multicolumn{2}{|c|}{ Tukey test } & NS & NS & NS & NS \\
\hline
\end{tabular}

B. Quantitative 3D analysis of compact bone tissue

\begin{tabular}{|c|c|c|c|c|c|c|}
\hline Group & $\mathbf{n}$ & $\begin{array}{l}\text { BV/TV } \\
(\%)\end{array}$ & $\begin{array}{c}\text { BMD } \\
\left(\mathrm{mg} \mathrm{HA} / \mathrm{cm}^{3}\right)\end{array}$ & $\begin{array}{c}\text { BV/TV* } \\
(\%)\end{array}$ & $\begin{array}{c}\text { Bs. } \\
\left(\mathbf{m m}^{2}\right)\end{array}$ & $\begin{array}{l}\text { Ct. Th. } \\
\text { (mm) }\end{array}$ \\
\hline $\mathrm{C}(1)$ & 4 & $0.51 \pm 0.16$ & $577.45 \pm 27.44$ & $0.96 \pm 0.01$ & $5.46 \pm 1.36$ & $0.194 \pm 0.01$ \\
\hline E1 (2) & 4 & $0.49 \pm 0.39$ & $543.60 \pm 60.37$ & $0.93 \pm 0.02$ & $5.11 \pm 2.14$ & $0.153 \pm 0.01$ \\
\hline E2 (3) & 4 & $0.47 \pm 0.13$ & $502.56 \pm 32.94$ & $0.94 \pm 0.01$ & $5.09 \pm 0.62$ & $0.185 \pm 0.02$ \\
\hline Tukey te & & NS & NS & NS & NS & $1: 2^{*} ; 2: 3^{*}$ \\
\hline \multicolumn{7}{|c|}{ C. Quantitative 3D analysis of trabecular bone tissue } \\
\hline Group & $\mathbf{n}$ & $\begin{array}{c}\mathrm{BV} / \mathrm{TV} \\
(\%)\end{array}$ & $\begin{array}{l}\text { Tb. N. } \\
(1 / \mathrm{mm})\end{array}$ & $\begin{array}{l}\text { Tb. Th. } \\
(\mathrm{mm})\end{array}$ & $\begin{array}{l}\text { Tb. Sp. } \\
(\mathrm{mm})\end{array}$ & $\begin{array}{c}\text { Bs. } \\
\left(\mathrm{mm}^{2}\right)\end{array}$ \\
\hline C (1) & 4 & $0.16 \pm 0.01$ & $4.62 \pm 0.03$ & $0.047 \pm 0.01$ & $0.21 \pm 0.01$ & $20.43 \pm 3.52$ \\
\hline E1 (2) & 4 & $0.15 \pm 0.04$ & $4.65 \pm 0.84$ & $0.039 \pm 0.01$ & $0.22 \pm 0.05$ & $25.12 \pm 6.07$ \\
\hline E2 (3) & 4 & $0.11 \pm 0.02$ & $3.95 \pm 0.55$ & $0.044 \pm 0.01$ & $0.25 \pm 0.04$ & $17.49 \pm 3.53$ \\
\hline \multicolumn{2}{|c|}{$\begin{array}{l}\text { Games-Howell/Tukey } \\
\text { test }\end{array}$} & $1: 3^{*}$ & NS & $1: 2^{*}$ & NS & NS \\
\hline
\end{tabular}

$\mathrm{n}$ : number of measurements; NS: non-significant differences; BV/TV - relative bone volume; BMD - bone mineral density; BV/TV* - relative bone volume without marrow cavity; Bs. - bone surface; Ct. Th. - cortical bone thickness; Tb. N. - trabecular number; Tb. Th. - trabecular thickness; Tb. Sp. - trabecular separation.

compact and trabecular bone tissues microstructure of mice. Our findings provide the first information related to taurine impact on bone microarchitecture after prolonged supplemental use.

Adverse effects of taurine (in high concentrations) on brain activity have also been demonstrated (Tsvetkova et al. 2015). Taurine is known to be an inhibitory neurotransmitter and neuromodulator. It is structurally analogous to gamma-aminobutyric acid, the main inhibitory neurotransmitter in the brain (Caine and Geracioti 2016). It can also stimulate the hypothalamus and modify the neuroendocrine function (Bidri et al. 2003). Since the skeleton is a direct target of hormonal action and it is also considered an endocrine 
organ that modulates glucose tolerance and testosterone production by a secretion of a bone-specific protein (Guntur and Rosen 2012), potential negative effects of taurine on bone microstructure could be connected with this phenomenon.

\section{Conflict of Interest}

There is no conflict of interest.

\section{Acknowledgements}

The study was supported by the projects VEGA 1/0653/16 and VEGA 1/0505/18.

\section{References}

BIDRI M, CHOAY P: Taurine: a particular amino acid with multiple functions. Ann Pharm Fr 61: 385-391, 2003.

BOUCKENOOGHE T, REMACLE C, REUSENS B: Is taurine a functional nutrient? Curr Opin Clin Metab Care 9: 728-733, 2006.

CAINE JJ, GERACIOTI TD: Taurine, energy drinks, and neuroendocrine effects. Cleve Clin J Med 83: 895-904, 2016.

CHOI MJ: Taurine may modulate bone in cholesterol fed estrogen deficiency-induced rats. Adv Exp Med Biol 975: 1093-1102, 2017.

CHOI MJ, CHANG KJ, LEE JW, JUNG YJ: Beneficial function of taurine on bone metabolism in alcohol-fed OVX rat model. Adv Exp Med Biol 975: 1059-1069, 2017.

CHOI MJ, SEO JN: Effect of taurine feeding on bone mineral density and bone markers in rats. Adv Exp Med Biol 776: 51-58, 2013.

EL IDRISSI A, OKEKE E, YAN X, SIDIME F, NEUWIRTH LS: Taurine regulation of blood pressure and vasoactivity. Adv Exp Med Biol 775: 407-425, 2013.

ENLOW DH, BROWN SO: Comparative histological study of fossil and recent bone tissues. Part I. Tex J Sci 8: 405, 1956.

GUNTUR AR, ROSEN CJ: Bone as an endocrine organ. Endocr Pract 18: 758-762, 2012.

MARTINIAKOVÁ M, GROSSKOPF B, OMELKA R, VONDRÁKOVÁ M, BAUEROVÁ M: Differences among species in compact bone tissue microstructure of mammalian skeleton: use of a discriminant function analysis for species identification. J Forensic Sci 51: 1235-1239, 2006.

MARTINIAKOVÁ M, BOBOŇOVÁ I, OMELKA R, GROSSKOPF B, STAWARZ R, TOMAN R: Structural changes in femoral bone tissue of rats after subchronic peroral exposure to selenium. Acta Vet Scand 55: 8-14, 2013.

OJA SS, SARANSAARI P: Pharmacology of taurine. Proc West Pharmacol Soc 50: 8-15, 2007.

REIM NS, BREIG B, STAHR K, EBERLE J, HOEFLICH A, WOLF E, ERBEN RG: Cortical bone loss in androgendeficient aged male rats is mainly caused by increased endocortical bone remodeling. $J$ Bone Miner Res 23 : 694-704, 2008.

RICQLÉS AJ, MEUNIER FJ, CASTANET J, FRANCILLON-VIEILLOT H: Comparative microstructure of bone. In: Bone 3, Bone Matrix and Bone Specific Products. Hall BK (ed.), Boca Raton: CRC Press, 1991, pp 1-78.

RIGGS BL, MELTON III LJ, ROBB RA, CAMP JJ, ATKINSON EJ, PETERSON JM, ROULEAU PA, MCCOLLOUGH CH, BOUXSEIN ML, KHOSLA S: Population-based study of age and sex differences in bone volumetric density, size, geometry, and structure at different skeletal sites. J Bone Miner Res 19: 1945-1954, 2004.

SCHAFFER SW, SHIMADA K, JONG CJ, ITO T, AZUMA J, TAKAHASHI K: Effect of taurine and potential interactions with caffeine on cardiovascular function. Amino Acids 46: 1147-1157, 2014.

TREUTING PM, DINTZIS SM: Comparative Anatomy and Histology: a Mouse and Human Atlas. Academic Press, 2011, 1-480 p.

TSVETKOVA DD, KLISUROV RC, PANKOVA S, ZLATKOV BA: Investigation of some pharmacological effects of caffeine and taurine in food supplements. Int J Nutr Food Sci 4: 18-23, 2015. 